\title{
PENINGKATAN PROFESIONALISME GURU-GURUBIOLOGI SMA DI KABUPATEN TULANG BAWANG BARAT MELALUI PELATIHAN PEMBUATAN MEDIA VIDEO TUTORIAL DANIMPLEMENTASINYA DALAM REMEDIAL TEACHING
}

\author{
Berti Yolida ${ }^{*}$, Rini Rita T. Marpaung, Wisnu Juli Wiono, Median Agus Priadi \\ Program Studi Pendidikan Biologi Universitas Lampung, Bandar Lampung \\ Jl. Prof. Sumantri Brojonegoro No.1 Bandar Lampung 35145 \\ Penulis Korespodensi : berti.yolida@fkip.unila.ac.id
}

\begin{abstract}
Abstrak
Guru sebagai tenaga pengajar dan pendidik dituntut untuk mampu merencanakan, melaksanakan, melakukan evaluasi, dan harus terampil dalam membuat dan memanfaatkan media pembelajaran. Salah satu kegiatan pembelajaran adalah Remedial teaching. Remedial teaching merupakan kegiatan pembelajaran bagi siswa yang belum memenuhi Kriteria Ketuntusan Minimal (KKM). Siswa yang belum tuntas umumnya pada materi yang berbeda-beda antara siswa satu dan yang lainnya. Hal ini menjadi kendala bagi guru dalam pelaksanakan kegiatan remedial teaching. Untuk itu guru harus memanfaatkan media pembelajaran. Guru-guru BIOLOGI SMA di Kabupaten Tulang Bawang Barat baik guru SMA Negeri maupun swasta selama ini belum terampil dalammembuat media pembelajaran serta memanfaatkannya khsusnya dalam remedial teaching. Oleh karena itu perlu adanya pelatihan terhadap guru-guru dengan tujuan meningkatkan keterampilan dan pemahaman guru-guru Biologi SMA di Kabupaten Tulang Bawang Baratdalam membuat media pembelajaran dan memahami strategi memanfaatkan media dalam remedial teaching. Metode yang digunakan dalam kegiatan ini adalah ceramah,demonstrasi,dan praktikmembuat media video tutorial, dan evaluasi. Hasil pelaksanaan kegiatan ini menunjukkan bahwa pelatihan yang dilakukan dapat meningkatkan pemahaman dan kemampuan guruguru dalam membuat media video tutorial dan implementasinya dalam pembelajaran remedial teaching. Sетиа guru maтри membuat dan menyelesaikan produk berupa media video tutorial dengan baik.
\end{abstract}

Kata kunci:Media, Remedial Teaching, Video Tutorial

\section{Pendahuluan}

Salah satu bentuk kompetensi pedagogi seorang guru adalah melaksanakan proses belajar mengajar yang aktif, menyenangkan dan kreatif. Diantara bentuk kegiatan belajar mengajar yang menarik dan menyenangkan adalah kegiatan belajar yang memanfaatkan teknologi dan informasi.Saat ini guru didorong untuk dapat mengembangkan media pembelajaran berbasis teknologi informasi.Untuk itu, guru masa kini harus 'melek' teknologi informasi dan komunikasi.Media yang digunakan guru memiliki peran penting pada setiap proses pembelajaran. Media memiliki posisi yang sangat strategis penggunaannya dalam proses pembelajaran, oleh karena itu guru selaku pendidik dituntut untuk dapat membuat dan menggunakan media di dalam menyampaikan materi pembelajaran maupun untuk mempermudah pencapaian tujuan belajar. Pendidik memiliki peran di dalam mengembangkan media pembelajaran sampai pada pemanfaatan dan penggunaan media pembelajaran. (Isma dan Luthpi: 2016).

Menurut Arsyad (2011: 3) kata media berasal dari bahasa Latin dan merupakan bentuk jamak dari kata medium yang secara harfiah berarti perantara atau pengantar. Hamidjojo dan Latuheru (Arsyad, 2011: 4) mengemukakan bahwa media sebagai bentuk perantara yang digunakan oleh manusia untuk menyampaikan atau menyebar ide, gagasan, atau pendapat sehingga ide, gagasan atau pendapat yang dikemukakan itu sampai pada penerima yang dituju. Sedangkan munurut Mufaroqah (2009) Media pendidikan digunakan dalam rangka komunikasi dan interaksi guru dan siswa dalam 
proses pembelajaran. Media pembelajaran dapat memperjelas penyajian pesan dan informasi sehingga dapat memperlancar dan meningkatkan proses dan hasil belajar. Menurut Susilana dan Riyana (2007) media video pembelajaran adalah media yang menyajikan audio dan visual yang berisi pesan-pesan pembelajaran baik yang berisi konsep, prinsip, prosedur, teori aplikasi pengetahuan untuk membantu pemahaman terhadap suatu materi pembelajaran.

Remedial teaching adalah pengajaran perbaikan. Remedial teaching dalam penerapannya adalah bertujuan untuk memberikan bantuan pada siswa yang ketinggalan belajar, siswa yang lamban, dan sukar menerima pelajaran, dengan kata lain adalah siswa yang berkesulitan belajar, dan membantu siswa dalam mencapai Kriteria Ketuntasan Minimal (KKM). KKM adalah nilai minimum yang harus dicapai oleh seorang siswa agar dapat dinyatakan tuntas dari mata pelajaran tertentu. Sebagaimana kita ketahui bahwa KKM ditentukan oleh sekolah masing-masing, dengan memperhatikan beberapa faktor seperti kompleksitas indikator (kesulitan dan kerumitan), daya dukung (sarana dan prasarana yang ada, kemampuan guru, lingkungan, dan juga masalah biaya), intake peserta didik (tingkat kemampuan rata-rata) awal siswa (Nur, 2008).

Remedial Teaching (Pengajaran Remedial) dilaksanakan untuk membantu siswa yang terlambat dalam memahami standar kompetensi. Pembelajaran remedial memberikan kesempatan kepada siswa untuk memahami kembali pokok bahasan yang telah diajarkan sebelumnya. Pembelajaran remedial hanya diikuti oleh siswa yang memerlukan pembelajaran tambahan(Selamet, 2017).

Terdapat 21 orang guru Biologi tingkat SMA di Kabupaten Tulang Bawang Baratyang mengajar di 17 sekolah negeri dan swasta.Jumlah yang sangat potensial jika diberikan pembinaan dan pembekalan tentang penggunaan media berbasis teknologi informasi.Berdasarkan daftar peserta Uji Kompetensi Guru (UKG) Biologi wilayah Kabupaten Tulang Bawang Baratterlihat bahwa sebagianbesar guru tersebut masih dalam rentang usia produktif, sehingga sangat potensial untuk meningkatkan keterampilan dalam bidang media komunikasi dan informasi. Disamping itu, para guru saat ini sudah tidak asing lagi dengan dunia komputerisasi namun sebagian besar guru belum memanfaatkan media secara optimal dalam menunjang kegiatan pembelajaran. Salah satu faktor yang membuat guru belum menggunakan media disebabkan karena masih minimnya kemampuan para guru dalam membuat media pembelajaran secara mandiri. Para guru mengalami kesulitan dan beraggapan bahwa membuat media pembelajaran sebagai suatu hal yang sulit dan membutuhkan waktu yang lama.

Berdasarkan fakta-fakta tersebut, maka hal ini dapat dijadikan sebagai dasar pendukung yang kuat untuk diadakannya kegiatan pelatihan pengembangan pembuatan mediapemblajaran berbasis TIK yang menggunakan aplikasi mudah digunakan dan membutuhkan waktu yang relatif singkat.

\section{Metode Kegiatan}

Keaiatan pelatihan pengembangan media pembelajaran berbasis video tutorial dan implementasinya dalam remedial teaching dilakasanakan di Kabupaten Tulang Bawang Barat, dengan peserta sebanyak 21 orang guru Biologi tingkat SMA yang mengajar di 17 sekolah. Metode yang digunakan dalam pelatihan ini adalah metode ceramah, metode demonstrasi, dan metode praktikum.

Berikut merupakan alur prosedur kerja yang digunakan dalam kegiatan pelatihan.

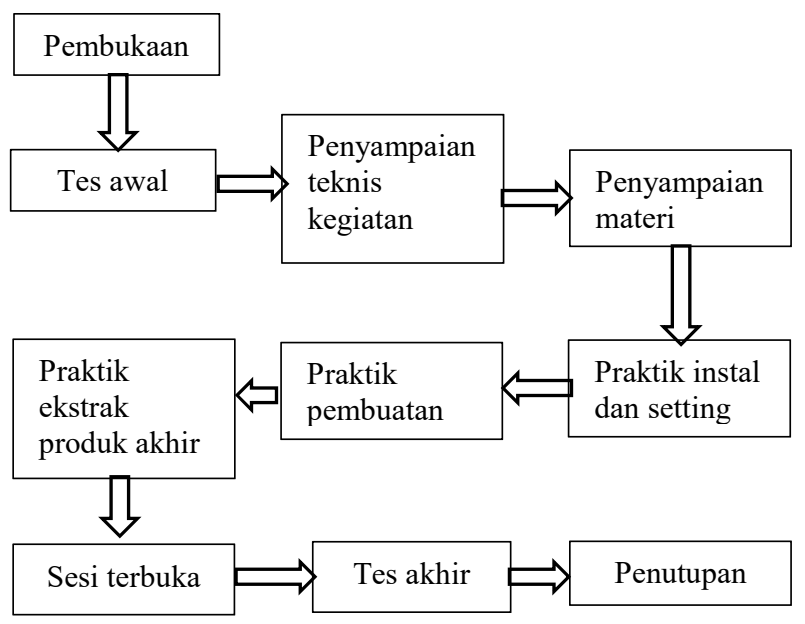

Gambar 1. Alur Prosedur Kerja Kegiatan Pelatihan

Tahapan pelaksanaan pelatihan dimulai dari tahap persiapan, dalam tahap ini terdapat koordinasi anggota tim instruktur untuk merencanakan pelaksanaan secara konseptual yang mencakup 
sistematika materi, modul serta instrument evaluasi kegiatan. Tahap kedua adalah pelaksanaan, yaitu kegiatan penyajian materi secara teoritis dan praktik langsung yang dipandu oleh tim instruktur, serta adanya evaluasi.

Evaluasi yang digunakan pada kegiatan ini adalah evaluasi mengenai keterampilan pembuatan media video. Selain itu keterampilan peserta dalam melaksakan kegiatan juga dinilai dengan menggunakan skala Likert sesuai Tabel 1 dan ditafsirkan dalam kriteria sesuai Tabel 2. Perhitungan persentase jawaban angket pada setiap pernyataan dengan menggunakan rumus sebagai berikut:

$\% X_{\text {in }}=\frac{\sum S}{S_{\text {maks }}} \times 100 \% \quad$ (Sudjana, 2005)

keterangan : $\% X_{\text {in }}=$ persentase jawaban pernyataan ke-i pada angket

$\sum S=$ jumlah skor jawaban total $S_{\text {maks }}=$ skor maksimum yang diharapkan

Tabel 1. Penskoran pada angket berdasarkan skala Likert.

\begin{tabular}{llc}
\hline No & \multicolumn{1}{c}{ Pilihan Jawaban } & Skor \\
\hline 1 & Sangat Terampil (ST) & 5 \\
2 & Terampil (T) & 4 \\
3 & Kurang Terampil (KT) & 3 \\
4 & Tidak Terampil (TT) & 2 \\
5 & Sangat tidak Terampil (STT) & 1 \\
\hline
\end{tabular}

Tabel 2. Tafsiran persentase angket (Arikunto, 2008)

\begin{tabular}{ll}
\hline Persentase & Kriteria \\
\hline $80,1 \%-100 \%$ & Sangat tinggi \\
$60,1 \%-80 \%$ & Tinggi \\
$40,1 \%-60 \%$ & Sedang \\
$20,1 \%-40 \%$ & Rendah \\
$0,0 \%-20 \%$ & Sangat rendah \\
\hline
\end{tabular}

\section{Hasil dan Pembahasan}

A. Analisis Evaluasi Awal Kegiatan

Sebelum penyajian materi pelatihan para guru terlebih dahulu melaksanakan kegiatanpretest mengenai remedial teaching dan media video tutorial. Pretest dilakukan untuk mengukur dan mengetahui kemampuan awal guru-guru dalam memahami kemampuan guru dalam membuat media pembelajaran.

Berikut disajikan rekapitulasi hasil pretest kegiatan pelatihan.

Tabel 3. Rekapitulasi Hasil Pretes

\begin{tabular}{|c|c|c|c|}
\hline $\begin{array}{c}\text { Nilai } \\
\text { terkecil }\end{array}$ & $\begin{array}{c}\text { Nilai } \\
\text { terbesar }\end{array}$ & $\begin{array}{c}\text { Rata- } \\
\text { rata }\end{array}$ & $\begin{array}{c}\text { Standar } \\
\text { deviasi }\end{array}$ \\
\hline 25 & 70 & 55 & 14,26 \\
\hline
\end{tabular}

Data pada Tabel 3 menunjukkan bahwa pemahaman awal yang dimiliki oleh peserta pelatihan terkait kemampuan membuat media dan remedial teaching kepada peserta pelatihan masih tergolong rendah, dengan rata-rata 55 dari skor ideal 80 dengan sandar deviasi sebesar 14,26.

B. Analisis EvaluasiAkhirKegiatan

Evaluasi akhir kegiatan pelatihan ini dilakukan setelah peserta menerima penjelasan materi dari dosen tim pelaksana. Evaluasi akhir kegiatan ini dimaksudkan untuk mengukur pemahaman peserta pelatihan mengenai remedial teaching dan evaluasinya serta pemahaman dan kemampuan guru dalam membuat media pembelajaran. Evaluasi akhir kegiatan inidilakukan dengan memberikan soal posttest. Soal posttest yang diberikan sama dengan soal pretest yangtelah diberikan sebelumnya. Berdasarkan hasil analisis posttest, berikut disajikan rekapitulasi hasil posttest kegiatan pelatihan.

Tabel 4. Rekapitulasi Hasil Postest

\begin{tabular}{cccc}
\hline $\begin{array}{c}\text { Nilai } \\
\text { terkecil }\end{array}$ & $\begin{array}{c}\text { Nilai } \\
\text { terbesar }\end{array}$ & Rata-rata & $\begin{array}{c}\text { Simpangan } \\
\text { Baku }\end{array}$ \\
\hline 65 & 95 & 80 & 8,25 \\
\hline
\end{tabular}

Hasil posttes mengenai pengetahuan guruguru biologi mengenai remedial teaching adalah sebagai berikut: nilai rata-rata guru-guru mengalami peningkatan antara sebelum dengan sesuah kegiatan pelatihan yakni 55 menjadi 80 atau dengan kata lain pemahaman guru mengalami peningkatan yang sangat signifikan.

Pada kegiatan posttest hanya diikuti oleh 17 peserta karena beberapa peserta lainnya tidak bisa mengikuti pelatihan sampai sore hari. Berdasarkan 
hasil evaluasi, kegiatan pelatihan ini dapat meningkatkan keterampilan guru dalam membuat media video tutorial untuk mendukung proses pembelajaran. Sebagian besar peserta mengungkapkan bahwa kemampuannya dalam membuat media pembelajaran sudah baik yaitu sebesar $82,4 \%$ dan $17,6 \%$ guru mengungkapkan kemampuannya sangat baik setelah mengikuti kegiatan. Hasil evaluasi disajikan pada gambar diagram berikut.

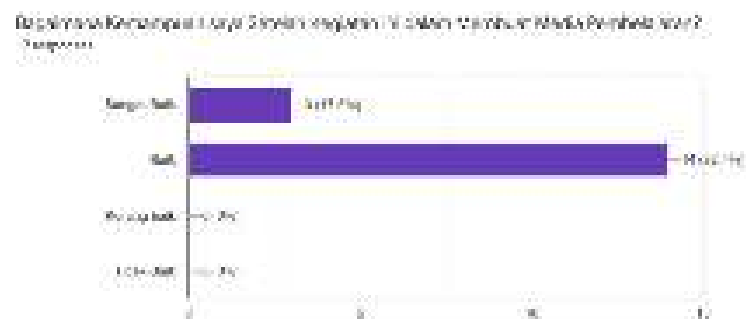

Gambar 2. Hasil Evaluasi Guru

Selain mengukur kemampuan guru dalam membuat media pembelajaran dan evaluasinya. Tim pengabdian juga melakukan evaluasi terkait urgensi pelaksanakan kegiatan pelatihan ini. Dari hasil evaluasi yang dilakukan menunjukkan bahwa semua guru berpendapat bahwa perlu ada kegiatan lanjutan mengenai pelatihan ini. 64,7\% guru mengungkapkan sangat perlu dan 35,3 menyampaikan bahwa kegiatan pelatihan lanjutan perlu diadakan kembali, seperti ditunjukkan gambar berikut.

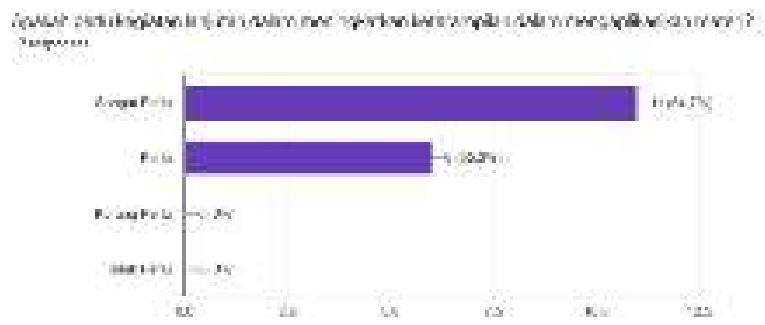

Gambar 3. Hasil Perlu Adanya Kegiatan Lanjutan

Berdasarkan hasil evaluasikegiatanpelatihan ini, terjadipeningkatan pemahaman yang tergolong Baik Hasil ini menunjukkan bahwa guru-guru sudah sangat terampil dalam membuat media video tutorial setelah guru mengikuti kegiatan pelatihan ini. Selain itu, semua guru sangat antusias dalam mengikuti kegiatan pelatihan hal ini terlihat motivasi guru yang sangat tinggi salama pelatihan. Para guru mengungkapkan bahwa aplikasi yang digunakan dalam membuat media ini sangat mudah sekali digunakan khususnya bagi guru-guru yang belum begitu memahami Informasi dan Teknologi. Media dapat dibuat dengan mudah namun hasilnya dapat digunakan sebagai media dalam pembelajaran bagi guru di kelas.Dengan demikian,pelatihaninitelah memberikan dampak positifterhadap peningkatan pemahaman tentang pembuatan media dan penerapannya dalam pembelajaran. Selain itu semua peserta sangat senang dengan adanya kegatan pelatihan ini dan $100 \%$ peserta bahkan menngungkapkan bahwa perlu adanya pelatihan lanjutan untuk peserta.

Optimalnya penyelenggaraan pelatihan ini tidak terlepas dari dari baiknya perencanaan dan koordinasi yang dilakukan oleh seluruh dosen tim pengabdian dalam merancang, menyusun materi dan pembagian tugas yang jelas pada masingmasing anggota tim. Selain itu setiap anggota tim pengabdian mengerjakan tugas dengan baik sesuai dengan kesepakatan yang telah ditetapkan serta saling berkoordinasi antar anggota tim. Hal ini menyebakan penyelenggaraan kegiatan pelatihan ini berjalan secara optimal. Optimalnya perencanaan dan penyelenggaraan kegiatan ini serta didukung oleh banyaknya pengalaman para pemateri dalam bidang pelatihan ini berdampak potitif bagi para guru-guru sehingga selama kegiatan pelatihan ini guru-guru merasa pelatihan ini sangat menyenangkan dan dapat menambah informasi dan ilmu pengetahuan baru tentang pembuatan media dan penerapannya dalam pembelajaran.

\section{Kesimpulan}

Berdasarkan hasil pembahasan dan temuan pada saat pelaksanaan pendampingan, maka dapat diambil simpulan sebagai berikut:

a. Peningkatan terjadi pada pengetahuan guru-guru biologiSMA di Tulang Bawang Barat mengenai remedial teaching, evaluasi dan implementasinya dalam pembelajaran.

b. Peningkatan terjadi pada kemampuan guru-guru biologi SMA di Tulang Bawang Barat dalam membuat media video tutorial pembelajaran dan evaluasi secara online.

c. Terdapat beberapa faktor pendukung dan penghambat dalam pelaksanaan pendampingan 
pemanfaatan dan pembuatan media video tutorial.

\section{Ucapan Terima Kasih}

Ucapan terima kasih disampaikan kepada FKIP Universitas Lampung yang telah mendanai kegiatan pelatihan ini melalui Dana BLU FKIP UNILA. Selain itu, ucapan terimakasih juga disampaikan pada Ketua (Musyawarah Guru Mata Pelajaran (MGMP) Biologi Tingkat Kabupaten Tulang Bawang Barat atas bantuan penyediaan tempat dan peserta pelatihan.

\section{Daftar Pustaka}

Arsyad, Azhar. 2011. Media Pembelajaran. Cetakan ke15. Jakarta: Rajawali Pers.

Maharani, Isma Nastiti dan Luthpi Saepuloh. 2016. Pelatihan Membuat Media Pembelajaran Berbasis IT Bagi Guru-Guru SMA Daarul Faalah Cisaat Kabupaten Sukabumi. Jurnal Surya: Seri Pengabdian kepada Masyarakat. 2 (1): 113-118: Universitas Muhammadiyah Sukabumi.

Mufarokah, Anissatul. 2009. Strategi Belajar Mengajar. Yogyakarta: TERAS.

Selamet. 2015. Pembelajaran remedial untuk meningkatkan ketuntasan belajar siswa. Jurnal An-Nuha 2 (1): 1.

Sholihah, Nur. 2008. Implementasi Program Remedial Teachingdalam Mencapai Kriteria Ketuntasan Minimal(KKM) Peserta Didik di Madrasah IbtidaiyahJenderal Sudirman Kota Malang. Malang: Universitas Islam Negeri (UIN) Malang.

Susilana, Rudi dan Cepi Riyana. 2007. Media Pembelajaran. Bandung: CV Wacana Prima 